\title{
In-vitro activity of peritoneal cells from rats after intra-abdominal infection with Bacteroides fragilis and Escherichia coli
}

\author{
W. R. VERWEIJ, F. NAMAVAR, W. F. SCHOUTEN, P. J. KOSTENSE*, M. PELLENKOFT, \\ J. DE GRAAFF† and D. M. MACLAREN
}

Vrije Universiteit, School of Medicine, Department of Medical Microbiology, Research Group for Commensal Infections, * Department of Theory of Medicine, Epidemiology and Biostatistics and $\dagger$ Department of Oral Microbiology, Academic Centre for Dentistry Amsterdam, Van der Boechorststraat 7, 1081 BT Amsterdam. The Netherlands

\begin{abstract}
Summary. Peritoneal cells from rats infected intraperitoneally with Escherichia coli and Bacteroides fragilis, alone or in combination were examined in vitro. Cells were harvested $6 \mathrm{~h}$ after implantation of fibrin clots infected with $E$. coli or $B$. fragilis, separately or containing both species, and assayed for their bactericidal capacities, chemiluminescence and production of cidal metabolites. Peritoneal cell populations from rats with implants of any of the infected clots showed similar distribution of different subpopulations. Bactericidal activity of peritoneal cells did not differ with the bacterial species used. Chemiluminescence values of peritoneal cells from rats with mono-infected $B$. fragilis or mixed-infected implanted clots, after stimulation with either particles or chemical stimuli, were significantly higher than those of rats with mono-infected E. coli or sterile clots. The same tendency was seen with regard to the production of cidal metabolites such as hydrogen peroxide and superoxide anions although no significant differences were found.
\end{abstract}

\section{Introduction}

Intra-abdominal abscess formation after peritoneal infection is considered to be the result of both bacterial sequestration and cellular factors. Fibrinous exudate together with thrombin forms fibrinous and ultimately fibrous adhesions. These are capable of capturing bacteria that are not cleared by the lymphatic system or killed by the indigenous macrophages and recruited leucocytes. Subsequent infiltration of these infected fibrin matrices by leucocytes and secretion of proteolytic enzymes result in a circumscribed collection of pus. However, abscess formation is more than the result of an inefficient or overloaded clearing and killing mechanism. ${ }^{1}$ In animal models of abscess formation it was shown that monomicrobial abscesses could be established only when either an extremely high inoculum was used or the strains were capsulate. ${ }^{2-4}$ Specific combinations of facultatively and obligately anaerobic bacteria, e.g., Escherichia coli and Bacteroides fragilis, on the other hand often resulted in abscess formation when clinically "significant" inocula were used, whether combined with adjuvant or not. ${ }^{5-8}$ In the case of the fibrin clot model, originally described by Ahrenholz and Simmons, ${ }^{9}$ the only "adjuvant" required with $E$. coli and $B$. fragilis was fibrinogen. ${ }^{2-10}$

Received 27 Feb. 1992; revised version accepted 20 April 1992.
In the present study this rat fibrin clot model was used to produce intra-abdominal abscesses. Previous work had shown that persistent abscesses formed when both $E$. coli and $B$. fragilis were present, ${ }^{10}$ but, individually, either $B$. fragilis or E. coli was cleared from the peritoneal cavity within $48 \mathrm{~h}$ and 2 weeks respectively. We defined a decisive moment in abscess formation $6 \mathrm{~h}$ after implantation of a mixed-infected fibrin clot. ${ }^{10}$ This point was marked by an increase in the viable counts of $B$. fragilis in the mixed-infected clot after an initial decrease. In the mono-infected $B$. fragilis clot viable counts decreased steadily and both bacteria and clot were removed within $24 \mathrm{~h}$. The present study was designed to investigate the cellular defence components of the peritoneum during the early stages of intra-abdominal mono- and mixed infection, and to determine whether the different sorts of infection had specific effects on cellular defence mechanisms. Cells of the peritoneal cavity were harvested $6 \mathrm{~h}$ after the implantation of mono- or mixedinfected fibrin clots. In-vitro assays were used to investigate bactericidal activity and production of cidal metabolites by the isolated cells.

\section{Materials and methods}

\section{Bacterial strains}

B. fragilis strain $\mathrm{BE} 1$ and $E$. coli strain $\mathrm{EB} 1$ are 
clinical isolates and have been used in previous studies. ${ }^{10}{ }^{12}$ Techniques of storage, growth conditions and ingredients of the minimal growth media have been described previously. ${ }^{10.13}$ Bacterial cultures (16h) were pelleted by centrifugation. washed and resuspended in Hanks's Balanced Salts Solution (HBSS. Gibco) supplemented with cysteine hydrochloride $0.5 \mathrm{mg} / \mathrm{L}$ for $B$. fragilis, and buffered saline $(\mathrm{NaCl}$ $0.9 \%, \mathrm{pH} 7.4)$, for $E$. coli " clot suspensions" and HBSS for "killing suspensions". The bacterial concentrations of the suspensions were adjusted to (1-2) $\times$ $10^{4} \mathrm{cfu} / \mathrm{ml}$ for $B$. fragilis and $(1-2) \times 10^{6} \mathrm{cfu} / \mathrm{ml}$ for E. coli; $5 \times 10^{*} \mathrm{cfu} / \mathrm{ml}$ of the bacterial suspensions were used in killing studies.

\section{Incorporation of hacteria into the fibrin clot}

Sterile and infected fibrin clots were prepared as described previously. ${ }^{10}$ Briefly, 100- $\mu$ l samples of the bacterial suspensions or the appropriate buffer were added to $1.4 \mathrm{ml}$ of human fibrinogen (Sigma) $2 \mathrm{mg} / \mathrm{ml}$. After mixing the tube contents gently, $200 \mu \mathrm{l}$ of thrombin (30 NIH units $/ \mathrm{ml}$ : Sigma) was added to catalyse fibrin clot formation.

\section{Animals}

Male Wistar rats (Harlan CPB. Zeist. The Netherlands) weighing $200 \mathrm{~g}$ on arrival were kept for a week before operation. During this period food and water were provided ad libitum. Fibrin clots. either sterile. mono- or mixed-infected, were implanted intraperitoneally (i.p.) ria a $2-3-\mathrm{cm}$ midline incision under ether anaesthesia. The incision was closed in two layers with four sutures each. Total anaesthesia time was $<10$ min. $^{10}$

\section{Preparation and characterisation of the peritoneal cell population}

The animals were killed by $\mathrm{CO}, 6 \mathrm{~h}$ after implantation of the fibrin clot. Peritoneal cells were harvested by lavage with $5 \mathrm{ml}$ of buffered saline supplemented with bovine serum albumin (BSA) $0 \cdot 2 \%$. Differential cell counts were made from cytocentrifuge preparations (Shandon Southern Instruments Ltd, 93-96 Chadwick Road. Runcorn. Cheshire) stained with May-Grünwald Giemsa in which at least 500 cells were counted.

\section{Measurement of killin!}

Peritoneal cell suspensions were washed and resuspended in HBSS with gelatin $0.1 \%$ and adjusted to a concentration of $1 \times 10^{-}$cells $/ \mathrm{ml}$. Viability of the cells was determined by trypan blue exclusion. Reaction mixtures were prepared in sterile polypropylene tubes $(12 \times 75 \mathrm{~mm}$. Greiner Labortechnik Ltd. Station Road. Cam. Dursley. Glos) each containing $0.5 \mathrm{ml}$ peritoneal cell suspension. $0 \cdot 1 \mathrm{ml}$ of normal rat serum
(NRS), $0.1 \mathrm{ml}$ of $E$. coli suspension $\left(5 \times 10^{\mathrm{R}} \mathrm{cfu} / \mathrm{ml}\right.$ in HBSS) and $0.3 \mathrm{ml}$ of HBSS with gelatin $0.1 \%$. Tubes were incubated aerobically at $37^{\circ} \mathrm{C}$ in an IKA Vibrofix shaking apparatus (Rofa Mavi, The Netherlands) at $400 \mathrm{rpm}$. After $30,60,90,120$ and $150 \mathrm{~min}, 100-\mu 1$ samples were suspended in $9.9 \mathrm{ml}$ of ice-cold distilled water and viable counts were performed by plating serial 10 -fold dilutions on nutrient-agar plates.

\section{Chemiluminescence $(C L)$}

The reaction mixture for $\mathrm{CL}$ consisted of $0 \cdot 1 \mathrm{ml}$ of peritoneal cell suspension $\left(5 \times 10^{6}\right.$ cells $/ \mathrm{ml}$ in HBSS without phenol red), $0.1 \mathrm{ml}$ of $0.1 \mathrm{~mm}$ luminol (Lumac, Switzerland), $0.2 \mathrm{ml}$ of phosphate-buffered saline (PBS) and $0.1 \mathrm{ml}$ of $80 \mathrm{~mm}$ phorbol 12-myristate 13acetate (PMA, Sigma). Samples were incubated at $37^{\circ} \mathrm{C}$ in a shaking water bath. $\mathrm{CL}$ was measured at $37^{\circ} \mathrm{C}$ in a Lumacounter model 2080 (Lumac) in the integral mode with a preset of $10 \mathrm{~s}$. The mean of counts during five 2-s periods was recorded. Peak CL values were expressed as a percentage of the peak value found with cells from rats in which a sterile fibrin clot was implanted.

\section{Measurement of hydrogen peroxide $\left(\mathrm{H}_{2} \mathrm{O}_{2}\right)$ release from peritoneal cells}

The release of $\mathrm{H}_{2} \mathrm{O}_{2}$ by the peritoneal cells was measured in a discontinuous phenol red oxidation assay. ${ }^{14}$ Briefly, wells of a 24 -well tissue-culture plate (Falcon, USA) were filled with $0.5 \mathrm{ml}$ of $56 \mathrm{~mm}$ phenol red solution in a buffer consisting of $140 \mathrm{~mm} \mathrm{NaCl}$, $10 \mathrm{~mm}$ phosphate buffer, $\mathrm{pH} 7.0$, and $5.5 \mathrm{~mm}$ dextrose. To this solution, $50 \mu \mathrm{l}$ of horseradish peroxidase ( $200 \mathrm{U} / \mathrm{ml}$, Sigma) and $50 \mu \mathrm{l}$ of $0.32 \mathrm{~mm}$ PMA was added. Finally $0.5 \mathrm{ml}$ of peritoneal cell suspension ( $1 \times 10^{7}$ cells $/ \mathrm{ml}$ in buffered saline) was added and plates were incubated aerobically at $37^{\circ} \mathrm{C}$ in a gently shaking water bath. After 30,60 and $120 \mathrm{~min}, 1-\mathrm{ml}$ samples were transferred to reaction vials containing $100 \mu \mathrm{l}$ of $0.2 \mathrm{M} \mathrm{NaOH}$. Samples were then centrifuged briefly and the optical density of the supernate was measured at $540 \mathrm{~nm}\left(\mathrm{OD}_{540}\right)$. Absolute amounts of $\mathrm{H}_{2} \mathrm{O}_{2}$ were calculated from a $\mathrm{H}_{2} \mathrm{O}_{2}$ standard curve.

\section{Measurement of superoxide anion $\left(\mathrm{O}_{2}^{--}\right)$release by peritoneal cells}

Release of $\mathrm{O}_{2}{ }^{--}$by peritoneal cells was measured with a discontinuous ferricytochrome $\mathrm{C}$ reduction assay. ${ }^{15}$ Briefly, wells of a 24 -well tissue culture plate (Falcon, USA) were filled with $0.5 \mathrm{ml}$ of $100 \mu \mathrm{M}$ cytochrome $\mathrm{C}$ solution (Boehringer, Mannheim, Germany). To this solution, $50 \mu \mathrm{l}$ of catalase $(1 \mathrm{mg} / \mathrm{ml}$, Sigma) and $50 \mu$ of $0.32 \mathrm{~mm}$ PMA were added. Finally $0.5 \mathrm{ml}$ of peritoneal cell suspension $\left(1 \times 10^{7}\right.$ cells $/ \mathrm{ml}$ in buffered saline) was added. Plates were incubated aerobically at $37^{\circ} \mathrm{C}$ in a gently shaking water bath. After 30,60 and $120 \mathrm{~min}, 1-\mathrm{ml}$ samples were trans- 
Table I. Peritoneal subpopulations after implantation of infected and sterile fibrin clots

\begin{tabular}{|c|c|c|c|c|c|c|}
\hline \multirow[b]{2}{*}{ Bacteria } & \multirow[b]{2}{*}{ cfu† } & \multicolumn{5}{|c|}{$\begin{array}{l}\text { Mean* percentage (SD) of cell subpopulations and total } \\
\text { cell number } 6 \mathrm{~h} \text { after clot implantation }\end{array}$} \\
\hline & & eosinophils & PMNL $\ddagger$ & macrophages & other cells§ & Total $\|$ \\
\hline $\begin{array}{l}\text { B. fragilis } \\
\text { and } \\
\text { E. coli }\end{array}$ & $\begin{array}{l}(1-2) \times 10^{8} \\
(1-2) \times 10^{5}\end{array}$ & $3(2)$ & $68(5)$ & $29(4)$ & $0(1)$ & $6.9 \times 10^{7}$ \\
\hline E. coli & $(1-2) \times 10^{5}$ & $4(2)$ & $61(4)$ & $34(4)$ & $1(1)$ & $5 \cdot 2 \times 10^{7}$ \\
\hline B. fragilis & $(1-2) \times 10^{8}$ & $2(1)$ & $72(4)$ & $26(3)$ & $0(1)$ & $7.2 \times 10^{7}$ \\
\hline None (sterile) & & $6(2)$ & $51(8)$ & $41(6)$ & $2(1)$ & $5.0 \times 10^{7}$ \\
\hline
\end{tabular}

\footnotetext{
* Mean of five independent experiments.

$\dagger$ Cfu inoculated in fibrin clot.

‡ PMNL minus eosinophils.

$\S$ Mast cells and lymphocytes.

$\|$ Total number of cells present in the rat peritoneal cavity (mean of five independent experiments).
}

ferred to reaction vials. Samples were then centrifuged briefly and the $\mathrm{OD}_{540}$ of the supernate was measured. Absolute amounts of $\mathrm{O}_{2}{ }^{--}$were calculated from the millimolar extinction coefficient of ferrocytochrome $\mathrm{C}$ $\left(\mathrm{Fe}^{2+}\right)$ of $21 \cdot 1$ at neutral $\mathrm{pH}$.

\section{Statistical analysis}

Analysis of variance (ANOVA) for a two-factor design with randomised blocks was applied to the CL peak values of five independent experiments which were done either singly or multiply. ${ }^{16}$ Regression analysis, after log transformation, yielded the $95 \%$ confidence intervals for the ratio of the detected contrasts. Results from all other tests were analysed by Student's $t$ test.

\section{Results}

\section{Peritoneal cell population}

Peritoneal cell populations of rats with monoinfected $E$. coli or $B$. fragilis, or mixed-infected fibrin clot implants were harvested $6 \mathrm{~h}$ after implantation of the clots and differentiated. Polymorphonuclear leucocytes (PMNL) were divided into eosinophils and other PMNL, mainly neutrophils. The remainder consisted of mast cells and lymphocytes.

Table I shows the percentages of the different cell types present $6 \mathrm{~h}$ after implantation of the fibrin clot. These data show that at the early stage of infection the composition of the peritoneal cell population of rats with infected implanted clots was very similar. Sterile clots, however, induced a smaller influx of peripheral blood cells resulting in a higher percentage of macrophages and eosinophils.

\section{Killing studies}

To determine whether the mono- and mixed infections had different influences on the capacities of peritoneal cells present $6 \mathrm{~h}$ after implantation of the fibrin clots, these cells were tested in a killing assay that detects the removal of bacteria by phagocytosis and

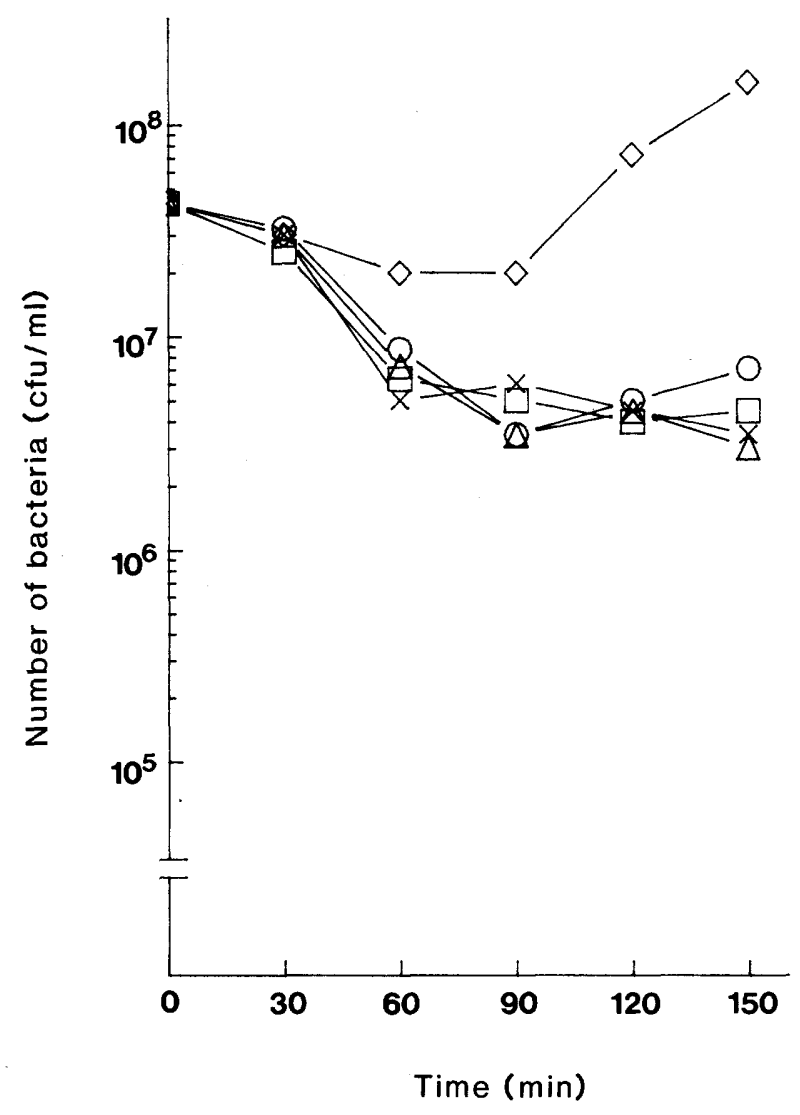

Figure. Killing of $E$. coli $\mathrm{EB} 1$ by peritoneal cells from rats, $6 \mathrm{~h}$ after implantation of: sterile fibrin clot $(\times) ; E$. coli-infected fibrin clot (O); B. fragilis-infected fibrin clot ( $\square$ ); double-infected fibrin clot $(\triangle)$; growth control $(\diamond)$.

subsequent killing by the peritoneal cells in the presence of NRS $10 \%$. The bacteria: phagocyte ratio was $10: 1$.

The figure shows the viable counts of $E$. coli EBI after incubation with peritoneal cells from rats with sterile, mono- or mixed-infected $E$. coli or $B$. fragilis fibrin clot implants. A reduction of $>90 \%$ in viable counts of E. coli was observed after $90 \mathrm{~min}$. E. coli viability was not affected by serum alone. No significant differences were found in the bactericidal capacity of peritoneal cells isolated $6 \mathrm{~h}$ after implantation of 
Table II. CL peak values of rat peritoneal cells isolated $6 \mathrm{~h}$ after implantation of the fibrin clot

\begin{tabular}{|c|c|c|c|}
\hline $\begin{array}{l}\text { Bacteria present } \\
\text { in clot }\end{array}$ & cfu* & $\begin{array}{l}\text { Percentage relative } \mathrm{CL} \\
\text { chemiluminescencet } \\
\text { (SEM) }\end{array}$ & $p$ value \\
\hline $\begin{array}{l}B \text { franilis } \\
\text { and }\end{array}$ & $(12) \times 10^{x}$ & $198(59)$ & $\stackrel{+}{+}$ \\
\hline E. coli & $(1-2) \times 10^{5}$ & & \\
\hline E. coll & $(1-2) \times 10^{3}$ & $131(38)$ & $0 \cdot 10965$ \\
\hline B. fratilis & $(12) \times 10^{n}$ & $173(56)$ & $0.0016 s$ \\
\hline None (sterile) & & 100 & \\
\hline
\end{tabular}

* Cfu inoculated in fibrin clot.

+ Maximum $C L$ values expressed as percentage of maximum values with peritoneal cells from rats with sterile fibrin clot impiants Values are expressed as mean (SEM) of five experiments.

* $\mathrm{P}$ value of effect modification $=0.6573$ (interaction between $E$. coll and $B$, fratilis).

\& $P$ value pertaining to main effects in two-way ANOVA.

mono-infected $E$. coli or $B$. fragilis clots or mixedinfected clots

\section{Chemiluminescence}

CL of the peritoneal cells was measured after stimulation with zymosan, bacteria and PMA. Whereas the absolute CL value differed between each stimulus, cells giving the highest $C L$ peak did so with all stimuli.

Table II shows the peak CL values, after stimulation with PMA, expressed as percentages of the maximum values found with cells from rats with sterile fibrin clot implants. Analysis of the data by the two-factor design yielded a $95 \%$ confidence interval for $E$. coli in the presence rersus absence of $B$. fragilis of $95-154 \%$, $\mathrm{p}=0.110$. For B. fragilis these values were $123-198 \%$, $\mathrm{p}=0.002$, indicating significantly elevated levels of $\mathrm{CL}$ due to the presence of $B$. fragilis in the infected clot. CL values of cells from rats with mixed-infected clot implants were also significantly elevated compared to those from rats with sterile clots. No statistical significance was found when comparing $E$. coli and $B$. frayilis $(\mathrm{p}=0.657)$.

\section{$\mathrm{H}_{2} \mathrm{O}_{2}$ and $\mathrm{O}_{?}^{*}$ production}

The amounts of $\mathrm{H}_{2} \mathrm{O}_{2}$ and $\mathrm{O}_{2}{ }^{\circ}$ produced by $10^{6}$ peritoncal cells after 30,60 and $120 \mathrm{~min}$ are shown in table III. Peritoneal cells from rats with sterile fibrin clots produced only small amounts of $\mathrm{H}_{2} \mathrm{O}_{2}$. No significant differences were found in the production of this metabolite by cells from rats with mono- or mixedinfected clots. Production of $\mathrm{O}_{2}{ }^{--}$was extremely low in all samples.

\section{Discussion}

In most studies, the effects of bacteria and bacterial products on host defences have been investigated with human peripheral blood PMNL. ${ }^{11.12,17}$ However, in this study we were interested in the defence capacities of host cells present in the peritoneal cavity during the early stages of intra-abdominal infection. Therefore, we used an animal model in which infected fibrin clots were implanted intraperitoneally in rats. The two bacterial strains used in this study, $B$. fragilis $\mathrm{BE} 1$ and E. coli $\mathrm{EB} 1$, lead to persistent abscess formation only when used in combination. This might result from a suppression of local host defences in mixed $E$. coli and $B$. fragilis infections. Therefore, we compared the efficacy of bacterial killing, CL and production of $\mathrm{H}_{2} \mathrm{O}_{2}$ and $\mathrm{O}_{2}{ }^{-}$by peritoneal cells from rats with mono- or mixed-infected fibrin clot implants. Cells were harvested from rats $6 \mathrm{~h}$ after implantation of the fibrin clot, since previous studies had shown that this was a decisive moment in abscess formation. ${ }^{10} \mathrm{Bac}-$ terial killing, under the assay conditions used in vitro, was efficient and proved to be independent of the bacterial species present in the implanted fibrin clot. Other investigators have shown that bacterial killing by human PMNL was markedly reduced on incubation with $B$. fragilis culture filtrate or short chain fatty acids (SCFA) such as succinate at low $\mathrm{pH} .{ }^{12,17}$ Rotstein et $a l^{17}$ suggested that the co-existence of SCFA, produced by $B$. fragilis, and a low $\mathrm{pH}$ may account for increased survival rates in mixed infection. These findings may have implications in vivo since Bryant et al. reported that $\mathrm{pH}$ values of human pus sometimes drop below $6 \cdot 0 .{ }^{18}$ However, other investigators have found that intraperitoneal $\mathrm{pH}$ changes during infection are only minor and never fall much below $\mathrm{pH} 6{ }^{19}$ Furthermore, there are no data on $\mathrm{pH}$ values or succinate concentrations within fibrin deposits during the early stages of infection. In this

Table III. Production of $\mathrm{H}_{2} \mathrm{O}_{2}$ and $\mathrm{O}_{2}{ }^{\circ}$ by rat peritoneal cells isolated $6 \mathrm{~h}$ after implantation of the fibrin clot

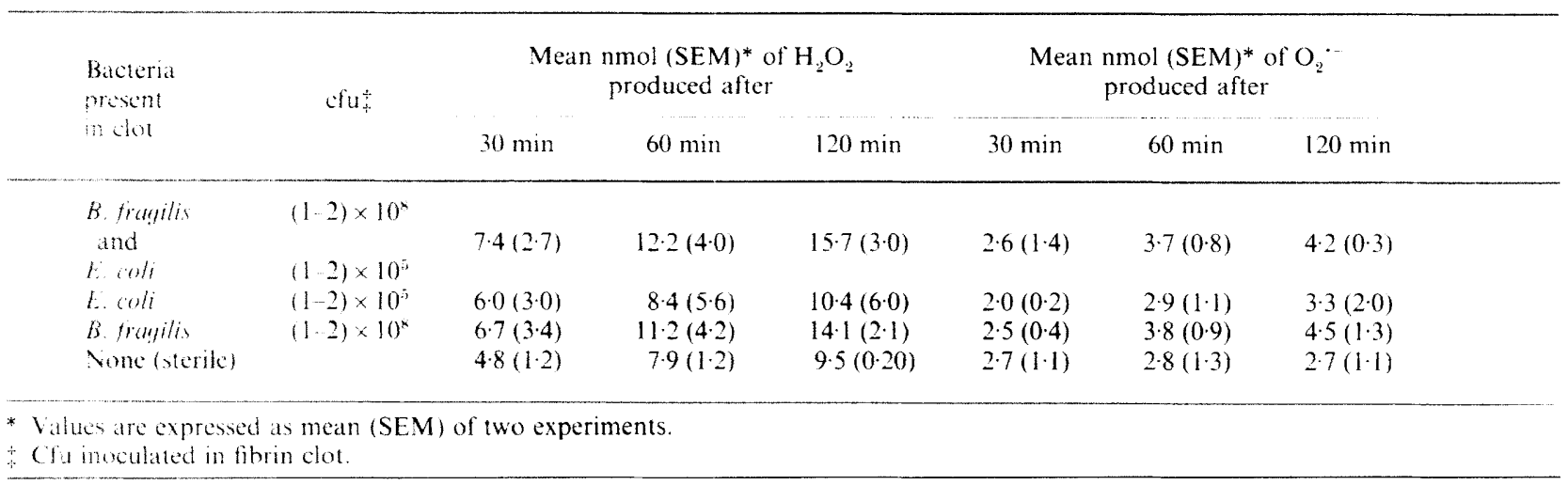


study, CL showed the highest response by peritoneal cells from rats with mono-infected $B$. fragilis and mixed-infected fibrin clot implants. This effect might be accounted for by the presence of $B$. fragilis itself or by metabolites produced during the first $6 \mathrm{~h}$. We excluded the possibility that these results were due only to a difference in priming of the peritoneal cells by a different number of particles, by testing cells from a rat with a fibrin clot implant containing $(1-2) \times 10^{8} \mathrm{cfu}$ of $E$. coli. CL values of these cells were only slightly higher than those of rats with a fibrin clot implant containing $(1-2) \times 10^{5} \mathrm{cfu}$, indicating that priming by greater numbers of micro-organisms does not account for the observed difference.

The production of $\mathrm{H}_{2} \mathrm{O}_{2}$ and $\mathrm{O}_{2}{ }^{-{ }^{-}}$by rat peritoneal cells involved in bacterial killing was also studied. The production of $\mathrm{H}_{2} \mathrm{O}_{2}$ by these cells proved to be independent of the bacterial species in the implanted fibrin clot. Priming of the peritoneal cells in vivo by the presence of bacteria induced a two-fold increase in response compared to the control (sterile clot), but no significant differences were found between cells from rats with mono-infections of $E$. coli or $B$. fragilis or mixed-infected clots. $\mathrm{O}_{2}{ }^{--}$production by rat peritoneal cells, as measured by ferricytochrome $\mathrm{C}$ reduction, was very low. Other investigators have demonstrated that $\mathrm{H}_{2} \mathrm{O}_{2}$ and $\mathrm{O}_{2}{ }^{--}$production by human PMNL in vitro was significantly reduced after incubation with several SCFA at $\mathrm{pH} 5 \cdot 5 .{ }^{20}$ This phenomenon was seen on stimulation with opsonised zymosan or PMA and proved irreversible. In our studies, peritoneal cells from rats with fibrin clot implants did not shown this phenomenon. This may

\section{References}

1. Dunn DL, Barke RA, Ewald DC, Simmons RL. Effects of Escherichia coli and Bacteroides fragilis on peritoneal host defences. Infect Immun 1985; 48: 287-291.

2. Rotstein OD, Kao J, Houston K. Reciprocal synergy between Escherichia coli and Bacteroides fragilis in an intraabdominal infection model. J Med Microbiol 1989; 29: 269-276.

3. Onderdonk AB, Kasper DL, Cisneros, RL, Bartlett JG. The capsular polysaccharide of Bacteroides fragilis as a virulence factor: comparison of the pathogenic potential of encapsulated and unencapsulated strains. $J$ Infect Dis 1977; 136: $82-89$.

4. Dunn DL, Rotstein OD, Simmons RL. Fibrin in peritonitis. IV. Synergistic intraperitoneal infection caused by Escherichia coli and Bacteroides fragilis within fibrin clots. Arch Surg 1984; 119: 139-144.

5. Nulsen MF, Finlay-Jones JJ, Skinner JM, McDonald PJ. Intraabdominal abscess formation in mice: quantitative studies on bacteria and abscess-potentiating agents. $B r J$ Exp Pathol 1983; 64: 345-353.

6. Onderdonk AB, Bartlett JG, Louie T, Sullivan-Seigler N, Gorbach SL. Microbial synergy in experimental intraabdominal abscess. Infect Immun 1976; 13: 22-26.

7. Hagen JC, Wood WS, Hashimoto T. Experimental intraabdominal abscess formation by Escherichia coli and Bacteroides fragilis. Eur J Clin Microbiol 1983; 2: 43-49.

8. Finlay-Jones JJ, Kenny PA, Nulsen MF, Spencer LK, Hill NL, McDonald PJ. Pathogenesis of intraabdominal abscess formation: Abscess-potentiating agents and inhibition of complement-dependent opsonization of abscess-inducing bacteria. J Infect Dis 1991; 164: 1173-1179.

9. Ahrenholz DH, Simmons RL. Fibrin in peritonitis. I. Beneficial indicate that local intraperitoneal conditions are not comparable with the assay conditions in vitro, or may reflect differences between human peripheral blood PMNL and rat peritoneal cells.

Investigators who used a mouse model of intraabdominal infection have looked at possible differences between abscess-derived and peritoneal exudate neutrophils. ${ }^{21-23}$ At first no differences were detected in functional properties of the cells such as phagocytosis of $P$. mirabilis, CR 3 expression and $\mathrm{H}_{2} \mathrm{O}_{2}$ production. However, analysis by flow cytometry of the respiratory burst after stimulation with bacteria in the presence of normal mouse serum revealed a variable, poorly responding subpopulation of neutrophils. The cellular defect causing this remains unknown.

The overall results of this study show that rat peritoneal cells isolated $6 \mathrm{~h}$ after implantation of mono- or mixed-infected fibrin clots demonstrated similar cellular activity. CL is the only assay that gave a clear distinction between cells from rats with sterile clots and those with monomicrobial or polymicrobial infection, suggesting involvement of myeloperoxidasedependent singlet oxygen. This could mean that the findings of abscess formation in vivo in the case of mixed infection fibrin clots are probably not due merely to altered defence capacities of the peritoneal cell population. However, local soluble factors of either bacterial or host origin, present in the peritoneum during the early stages of infection, could influence cellular defence. We are currently studying the role of soluble factors on host defence in this rat model after implantation of mono- and mixed-infected fibrin clots.

and adverse effects of fibrin in experimental $E$. coli peritonitis. Surgery $1980 ; 88: 41-47$.

10. Verweij WR, Namavar F, Schouten WF, MacLaren DM. Early events after intra-abdominal infection with Bacteroides fragilis and Escherichia coli. J Med Microbiol 1991; 35: 18-22.

11. Vel WAC, Namavar F, Verweij-Van Vught AMJJ, Pubben ANB, MacLaren DM. Killing of Escherichia coli by human polymorphonuclear leucocytes in the presence of Bacteroides fragilis. J Clin Pathol 1985; 38: 86-91.

12. Namavar F, Verweij-Van Vught AMJJ, Bal M, MacLaren DM. Effect of Bacteroides fragilis cellular components on chemotactic activity of polymorphonuclear leucocytes towards Escherichia coli. J Med Microbiol 1987; 24: 119-124.

13. Namavar F, Verweij AMJJ, Bal M, van Steenbergen TJM, de Graaff J, MacLaren DM. Effect of anaerobic bacteria on killing of Proteus mirabilis by human polymorphonuclear leucocytes. Infect Immun 1983; 40: 930-935.

14. Metcalf JA, Gallin JI, Nauseef WM, Root RK. Laboratory manual of neutrophil function. New York, Raven Press. 1986: 110-111.

15. Metcalf JA, Gallin JI, Nauseef WM, Root RK, Laboratory manual of neutrophil function. New York, Raven Press. 1986: $125-126$

16. Armitage $P$, Berry $G$. Statistical methods in medical research, 2nd edn. Oxford, Blackwell. 1987: chapter 8.

17. Rotstein OD, Vittorini T, Kao J, McBurney MI, Nasmith PE, Grinstein S. A soluble Bacteroides by-product impairs phagocytic killing of Escherichia coli by neutrophils. Infect Immun 1989; 57: 745-753.

18. Bryant RE, Rashad AL, Mazza JA, Hammond D. $\beta$-Lactamase activity in human pus. $J$ Infect Dis $1980 ; 142$ : 594-601

19. Sawyer RG, Spengler MD, Adams RB, Pruett TL. The 
peritoneal environment during infection. The effect of monomicrobial and polymicrobial bacteria on $\mathrm{pO}_{2}$ and pH. Ann Surq 1991: $213: 253-260$.

20. Rotstein OD, Nasmith PE, Grinstein S. The bacteroides byproduct succinic acid inhibits neutrophil respiratory burst by reducing intracellular $\mathrm{pH}$. Infect Immm 1987; 55: 864870.

21. Hart PH. Spencer LK. Nulsen MF. McDonald PJ. Finlay-Jones J. Neutrophil activity in abscess-bearing mice: Com- parative studies with neutrophils isolated from peripheral blood. elicited peritoneal exudate, and abscesses. Infect Immun 1986; 51: 936-941.

22. Kenny PA, Spencer LK, McDonald PJ, Finlay-Jones JJ. Functional activity of individual abscess neutrophils from mice. Infect Immun 1990; 58: 40044010 .

23. Finlay-Jones JJ. Hart PH. Spencer LK, Nulsen MF, Kenny PA, McDonald PJ. Bacterial killing in vitro by abscess-derived neutrophils. J Med Microbiol 1991: 34: 73-81. 